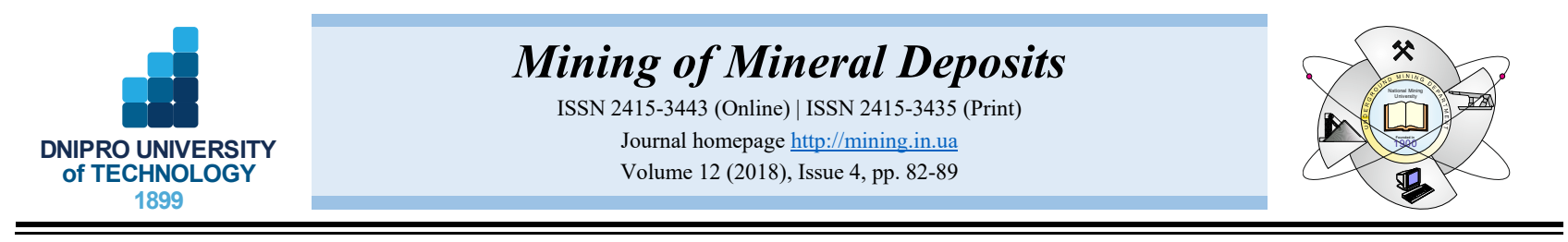

UDC 330.34:336.02:338.1

https://doi.org/10.15407/mining12.04.082

\title{
TOPICAL PROBLEMS CONCERNING BOTH METHODS AND ECONOMY TO DEVELOP MINERAL DEPOSITS
}

\author{
O. Vagonova ${ }^{1 *}$, T. Mormul ${ }^{1}$, Yu. Zakharchenko ${ }^{2}$, N. Romaniuk ${ }^{1}$, L. Kasianenko ${ }^{1}$ \\ ${ }^{1}$ Dnipro University of Technology, Dnipro, Ukraine \\ ${ }^{2}$ State Agrarian and Economic University, Dnipro, Ukraine \\ *Corresponding author: e-mail vagonovaag@gmail.com, tel. +380677741527
}

\begin{abstract}
Purpose. Development of mining enterprises adaptation to changes in conjuncture of a product market relying upon its competitiveness while reducing expenditures connected with mineral stock extraction at the expense of mining operation schedule reorganization in accordance with market demand for their products.

Methods. Methodological approach to provide output competitiveness in the context of its adaptation to market demand has been substantiated with the use of correlation analysis technique taking into consideration variability of outgoing data and their uncertainty. A technique to support competitive product advantages has been identified on the basis of operations function of mining complex since the advantages depend heavily on the expenses connected with crude ore. Cost changes effected by a market demand have been estimated basing upon feasibility analysis of operations of open pits selected to be considered.
\end{abstract}

Findings. Relations between crude ore mining, prime cost of ore mining and processing enterprise product of Ukraine and market demand for their output have been determined. The current open pit expenditures, connected with ore bed mining, have been specified; process solutions, concerning the operating mining complex modernization, has been substantiated basing upon them. Extraction system effect on the mining complex technological adaptation to lower demand for manganese ore has been stated.

Originality. Scientific and application foundations to obtain competitive advantages for the product manufactured by mining and processing enterprises by means of technological adaptation of mining complexes to market demand have been developed. Adaptation instruments of the complexes have been estimated with the help of the production function. Methodological approach to plan crude ore prime cost, basing upon expenditures, connected with overburden operations, has been improved.

Practical implications. In the context of Pivnichnyi and Zaporizkyi open pits, the effect of extraction volumes on the mined ore prime cost has been determined; the effect has been involved to substantiate economically the expedient system for ore bench mining. Production function of Pivnichnyi open pit has been defined. Its analysis results helped formulate recommendations concerning labour shedding and production increase.

Keywords: mining and processing enterprise, manganese open pits, production function, competitiveness, product

\section{INTRODUCTION}

Almost $50 \%$ of industrial potential in Ukraine and up to $20 \%$ of its labour resources are connected with mineral mining and use (National program..., 2018). When Ukraine was becoming independent state, it exported out $32 \%$ of coal, and $15 \%$ of iron and steel of the total USSR export (Shutov, 2012). Coal is the main strategic fuel and energy resource of Ukraine, which is able to ensure the development of the leading economic sectors, in particular the production of electrical power and metallurgy for the next 300 - 400 years (Rudko, Kurylo, \& Bala, 2016;
Petlovanyi, Lozynskyi, Saik, \& Sai, 2018). The fuel situation in the country demands developing an effective mechanism for delimiting economic feasibility of coal extraction (Pivnyak, Pilov, Bondarenko, Salli, \& Yashchenko, 2005; Piwniak, Bondarenko, Salli, Pavlenko, \& Dychkovskiy, 2007). Under the current conditions of market economy, a share of oil products within the total amount of commodity imports increased by $14.3 \%$; in the context of iron ores and concentrates - by $10 \%$ (Koltunovish, 2014). That effected adversely many industries as well as on the whole economy. Activities of many mining enterprises, performed under extremely compli-

(C) 2018. O. Vagonova, T. Mormul, Yu. Zakharchenko, N. Romaniuk, L. Kasianenko. Published by the Dnipro University of Technology on behalf of Mining of Mineral Deposits. This is an Open Access article distributed under the terms of the Creative Commons Attribution License (http://creativecommons.org/licenses/by/4.0/),

which permits unrestricted reuse, distribution, and reproduction in any medium, provided the original work is properly cited. 
cated conditions, have resulted in significant production cutback, and unsatisfactory economic operations (Vagonova \& Volosheniuk, 2012; Vagonova, Prokopenko, \& Kyrychenko, 2014).

Implementation of new, more flexible techniques, meeting the requirements of the modern market, is one of the components of successful operations of mining enterprises (Strpić, Miličević, \& Kurevija, 2017). Adaptation of production facilities of mining and processing integrated works (MPIWs) to the mineral stock market conjuncture is the prerequisite to solve the problem today. Moreover, the adaptation depends upon certain regularities concerning changes in mining parameters as for the expediency of the available open pit systems use (Temchenko, 2014). Updating of the systems as well as putting into operation of new systems will involve new engineering, technological approaches, and economic substantiation of the solutions (Dychkovskyi, Avdiushchenko, Falshtynskyi, \& Saik, 2013).

Both engineering and economy of a deposit extraction defines production potential of any mining enterprise (Kravchuk \& Andreieva, 2012). In the context of market economy, the potential effects the current competitiveness as well as potential competitiveness of mineral stock being mined (Ponomarenko \& Sultani, 2009). On the one hand, capacity development of enterprises needs innovative mining techniques and open pit equipment to provide admissible expenditures, connected with mineral stock extraction; on the other hand, economic substantiation of the mineral stock extraction volumes in accordance with market demand for it (Tatarkin, Kornolkov, Yakovlev, \& Orlova, 2012). According to findings, stated by (Voloshyna \& Kostakova, 2017), both character and amount of natural factors influence on the cost changes in technological chain in the context of mining and processing should involve detailed consideration. Thus, to determine a potential of titanium-zirconium stock market, its grade, reserves, mining conditions to develop the deposits as well as geographical and economic arrangement of the enterprises, consumer requirements for the product, and natural resource cost have been considered (Melnikov, Sobko, \& Pundiak, 2012). A potential of the global dioxide titanium market has been determined relying upon statistic estimations of production capabilities in comparison with actual facilities of mining enterprises in the world and in Ukraine.

Authors of paper (Bilotserkivets \& Zavhorodnia, 2017) emphasize that production potential of mining enterprises reflects technological characteristics of the industry progress, namely: modernization level and a level of deposit development in the regions with poorly developed infrastructure, and possibility to use system approach at the prognosis stage. Efficient operation schedules to mine minerals have been analyzed according to the criteria of rational use of natural resources and recommended for introduction (Mormul \& Terekhov, 2017).

As for the problem, being solved, appropriateness of the approach to form enterprise potential on its competitive advantages flows from paper (Naumenko, 2013). According to the conclusions by O.V. Naumenko, attractiveness of a product, manufactured by any enterprise, is determined by a set of various factors depending upon entrepreneurial goals, and production and technical characteristics in the past, at the moment, and prospectively. A model of macroeconomic mechanism of governmental investment expansion has been improved; propositions concerning stimulation the progress of mining and metallurgical industry have been developed (Vahonova \& Romaniuk, 2014; Ranängen \& Lindman, 2017). The factors of external environment of enterprises, effecting the functioning of their competitiveness management, have been systemized (Savchenko, 2015). In this context the future sustainable development as well as circular economy has been widely studied and examined (Ursul \& Ursul, 2015; Smol, Kulczycka, \& Avdiushchenko, 2017; Ursul, Ursul, \& Dugarova, 2017).

In the days of Socialist Ukraine, use of powerful equipment for production processes by mining enterprises was required from the viewpoint of satisfaction of raw materials requirements of adjacent enterprises and from the viewpoint of prime cost reduction at the expense of industrial scale. The current economic changes, taking place in the country, result in the drastic reduce of the scale; hence, such support of available methods and technology turned out to be inexpedient. Due to poor adaptation to market conjuncture, and imbalance between operation schedules and economic requirements for a deposit development, certain mining and processing integrated works decreased their output significantly. The enterprises did not focus extensively on their behavioral strategy adjustment in the context of competitive environment as well as methods and technology redesign with slump in demand for metallurgical raw material.

Hence, the potential of mining and processing enterprise as well as the industry taken as a whole depends upon many factors. Extra potential, which cannot be used by the enterprise, just worsens its competitiveness; however, if demand for the product increases, the potential will favour its economic results. No enterprise can influence heavily on the demand; nevertheless, it can support competitive advantages of its product at the expense of the price and quality (Vagonova \& Prokopenko, 2017).

The solutions, mentioned in tractates, need further development of scientific and application foundations to adapt mining enterprises to changes in market conjuncture which should rely upon substantiating the improvement paths for operation schedule of a mineral mining according to market demand for the product. Just solving the problem determined the paper objective.

Reconstruction of enterprise facilities as well as improvement of mining operations may be considered as one of the tendencies to adapt it to market environment (Opara, Buzina, \& Vynohradenko, 2017). That helps reduce prime cost while developing a manoeuvre for price competitiveness or fatten the profits at the expense of less expensive large-scale marketing etc.

\section{METHODS}

First, the above stipulates the necessity of statistic evaluation of economic business results; among other things, it concerns production function of enterprises as indices of their adaptation to market environment. The evaluation is performed with the use of correlation analysis methods making it possible to substantiate ways for 
the product competitiveness as for market demand. The techniques are based upon the averaged output data varying under the influence of different factors (external factors mainly); thus, they take into consideration both variability of business environment and its uncertainty. It follows that in general, any enterprise should work hard within competitive environment while struggling for its goods market.

Production function has been used to evaluate the support of competitive advantages of a product manufactured by MPIW. Following expression describes dependence between $Q$ of a product, being manufactured, and resources of capital assets $F$-and labour $P$ :

$Q=K \cdot F^{\alpha} \cdot P^{\beta}$,

where:

$K$ - a coefficient characterizing production efficiency (depending upon cost unit dimension and output);

$\alpha, \beta$-coefficient of production flexibility as for the money consumption and labour expenditures.

Expenditures, connected with the MPIW product depend upon crude ore expenditures. Hence, production function is determined and analyzed. Relying upon the function, production factors are identified basing on which the extracted raw material amount can be managed successfully. If open pit output decreases, then total production costs will decrease disproportionately slow resulting in the accelerated increase in the extracted ore prime cost. The conclusion is checked using engineering-economic analysis of practices of open pits selected to be considered. In the context of the aspect, being under study, the method to mine ore bed, is characterized by certain disadvantages; thus, further decision making concerning such an engineering solution which will help lower prime cost of manganese crude ore, determine the disadvantages as well as methodological approach capable of their avoiding. Restructuring of enterprise and its operating processes is the decision if production cost is decreased.

\section{RESULTS AND DISCUSSION}

The studies on the paper topic concerned Pokrov MPIW (PMPIW). The integrated works has sufficient reserves of crude ore and labour resources to meet a wide range of requirements. Below you can find data of product output concerning the influence of market demand on the production process (Table 1).

Table 1. Production capacity, thous. t/year

\begin{tabular}{lccc}
\hline & Projected & Achieved & Current \\
\hline $\begin{array}{l}\text { Crude ore extraction } \\
\text { Manganese concen- }\end{array}$ & 9300 & 7100 & 1900 \\
$\begin{array}{l}\text { trate production } \\
\begin{array}{l}\text { Agglomerate } \\
\text { production }\end{array}\end{array}$ & 4920 & 2280 & 600 \\
\hline
\end{tabular}

Pokrov MPIW is the world largest enterprise producing manganese concentrate and agglomerate for ferroalloy enterprises and metallurgical enterprises in Ukraine and to be exported to countries of the near abroad and far-abroad countries. Eight open pits operated in the times of centrally planned economy when Socialist Ukraine existed. The open pits were equipped with high productive facilities which mined up to $200 \mathrm{mln} \mathrm{m}^{3}$ of rock mass. Nine rotor systems with productivity of 5 to 7 thousand cubic meters per hour, forty-three 6 to $20 \mathrm{~m}^{3}$ bucket draglines, seventy-nine excavators of direct shovel type with 5 to $8 \mathrm{~m}^{3}$ capacity, thirty-five train sets of cars, and more than 500 dumpers were engaged in overburden operations. Three plants concentrated manganese ore. Agglomerate plant, transportation and repair departments as well as other supporting services are integral parts of the integrated works.

During the last decade, amount of crude ore, extracted by open pits, decreased from 4500 down to 1200 thousand $t /$ year to be explained by strong conjuncture of crude ore market. Decreased extraction amounts resulted in the increased prime cost of the integrated works product and its decreased competitiveness (Fig. 1). Moreover, demand for MPIW product fluctuates; to satisfy it, security stocks of concentrate are accumulated. Hence, expenditures connected with ore extraction and concentration increase to compare with the expenditures to be reversed according to actual shipping amounts. Thus, resulting from production imbalances and imbalances of the product shipping, the integrated works should "freeze" certain amount of financial resources.

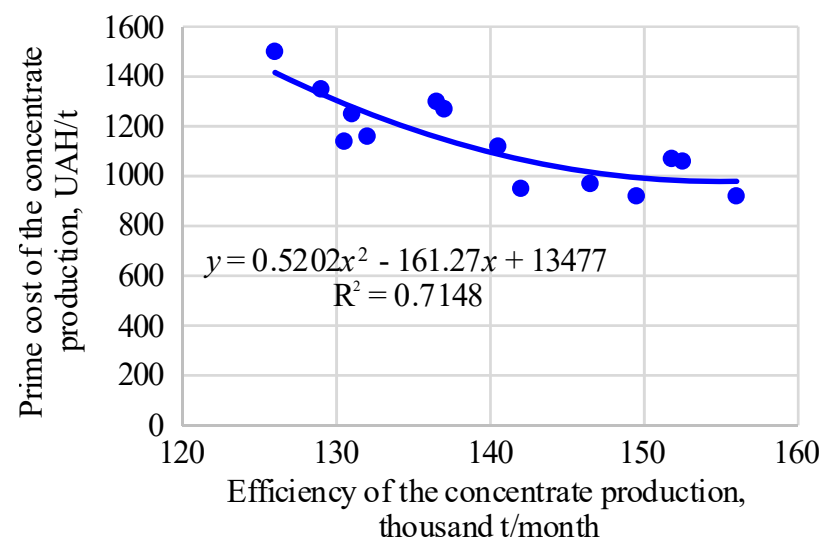

Figure 1. Graph of manganese concentrate prime cost dependence upon its production output

To determine supporting means for the product competitiveness, production function of mining complex has been considered according to statistic data of Pivnichnyi open pit of MPIW. Such powerful draglines as ESh15/90A, ESh-20/90, and ESh-10/70A; three EKH-5, and EKH-5AU excavators; and accessory equipment (fortyeight units in total) were delivered. In terms of the current value of Ukrainian money, capital assets increased from UAH $416 \mathrm{mln}$ up to $457 \mathrm{mln}$; number of personnel decreased from 482 down to 415 . In the context of the stable functioning, the open pit output varied annually: 35.6 to $55.3 \mathrm{mln}$ tons as for the rock mass, and 1.0 to 1.4 $\mathrm{mln}$ tons as for the crude ore. Following function characterizes the open pit operations:

$Q_{K}=9.346 \cdot 10^{-5} F^{1.582} P^{1.179}, \mathrm{mln}$ tons/year,

where:

$F$ - resources of capital assets, UAH, mln;

$P$ - number of employees.

Analysis of function (2) has shown the following. The use of the powerful draglines stipulates labour shed- 
ding, and increases the open pit efficiency despite the fact that capital assets experience minor increase since the draglines are cheap equipment to compare with rotor systems. Open pit, applying transportless mining system, responses more operatively to the increase in assets and personnel to compared with open pits where transport and dumping system is used. The obtained function is characterized by a feature as for labour and assets substitutability. Coefficient sum is $\alpha+\beta>1$; thus, the function with the increasing return of the manufacturing scale corresponds to the intensive economic growth; moreover, $\alpha>\beta$ to be labour-intensive increase factor. It means that the increased cost results in inadequate high increase in production. Such a case is explained by a great number of new equipment put into operation as well as drastic changes in the production method and its management. At the same time, significant decrease in the MPIW product demand eliminates the need in the increased production while stipulating considerable decrease in its achieved amount.

Influence of mining volume on the prime cost of overburden and manganese ore extraction has been analyzed. Statistic estimation of the indices relation has been performed in the context of Pivnichnyi and Zaporizkyi open pits. During the estimation period, Pivnichnyi open pit was at the stage of its full growth; Zaporizkyi open pit was almost mined-out with quite low efficiency.

Overburden operations are the basic component of production cost while crude ore extracting (i.e. $80-85 \%$ ); prime cost of the operations increases considerably if their volume drops due to significant increase in the specific semi-fixed costs since they are $60-70 \%$ of total overburden expenditures when ore mining is $33-38 \%$, and concentrate production is $46-50 \%$. The dependences, being considered, are characterized by rather high determination coefficient (i.e. $R^{2}=0.79-0.88$ as it is seen in Fig. 2).

Figure 3 demonstrates dependences of ore prime cost on mining output in the form of graphs. The graphs confirm the fact that increase in the mining enterprise efficiency results in the crude ore prime cost decrease; on the contrary, the latter increases if productivity drops (i.e. $R^{2}=0.50-0.92$ ). Moreover, in terms of the graphs, mining process prime cost decreases slowly when its amounts are considered in the context of considerable values; if the amounts decrease, it grows rapidly in the context of minor values. That can explain the increase in the MPIW product if its amount drops due to sales slowdown (Fig. 3).

Relying upon the obtained statistic dependences, concerning the open pits under consideration, the following has been determined:

1) expenses for materials and fuel depend weakly on mining output (i.e. $R^{2}=0.16-0.23$ ) since their formation does not involve overburden and extraction amounts;

2) budget items, concerning prime cost of mining operations, demonstrate the closest relationship between the open pit productivity (as for its overburden operations and extraction operations) and electric power cost (i.e. $R^{2}=0.93$ ). (a)

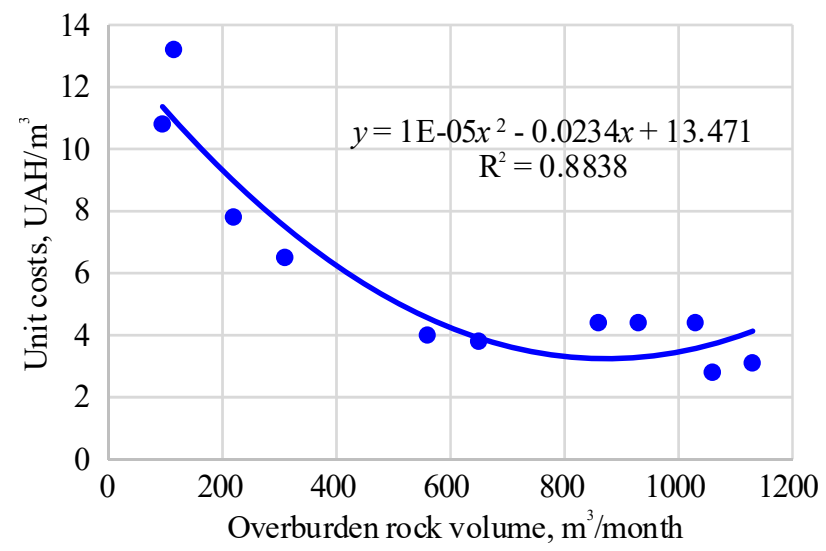

(b)

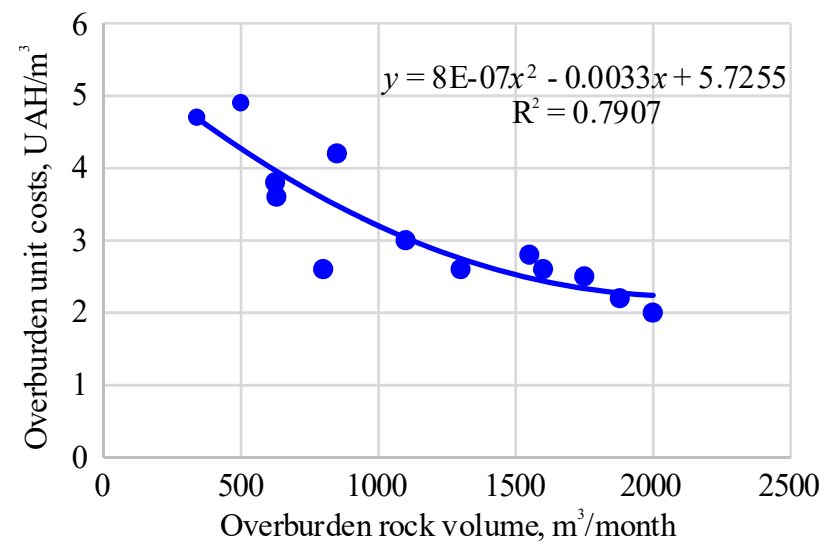

Figure 2. Graph of units costs dependence upon overburden volume in the context of Zaporizkyi open pit (a) and Pivnichnyi open pit (b)

Below you can find a decision-making process intended to decrease manganese ore prime cost. The studies have been carried out for the conditions of ore bed mining in the context of Pivnichnyi open pit. In the context of the aspect, being considered, the mining method, applied for the open pit, has following disadvantages:

1) ore is extracted and stockpiled temporarily at the surface of a stocker with the help of a dragline. That can provide neither qualitative extraction of the ore nor complete one;

2) belt conveyors, used in this context, lengthen overburden transportation to the stocker while increasing expenditures for overburden operations;

3 ) total productivity of the equipment, used for overburden operations, can be much higher to compare with that, required for ore reserves overburdening in the scope of its potential sales.

To avoid the disadvantages, the improved method should be based upon solutions matching the following:

1) in the context of the open pit, ore has to be extracted using separated bench; the product should be transported with the help of loaders and dumpers;

2) the mining technique provides cross travel of overburden rocks to a stocker (no conveyors are used); and

3) equipment system provides manganese ore mining in the scope, corresponding to its potential sales. 
(a)

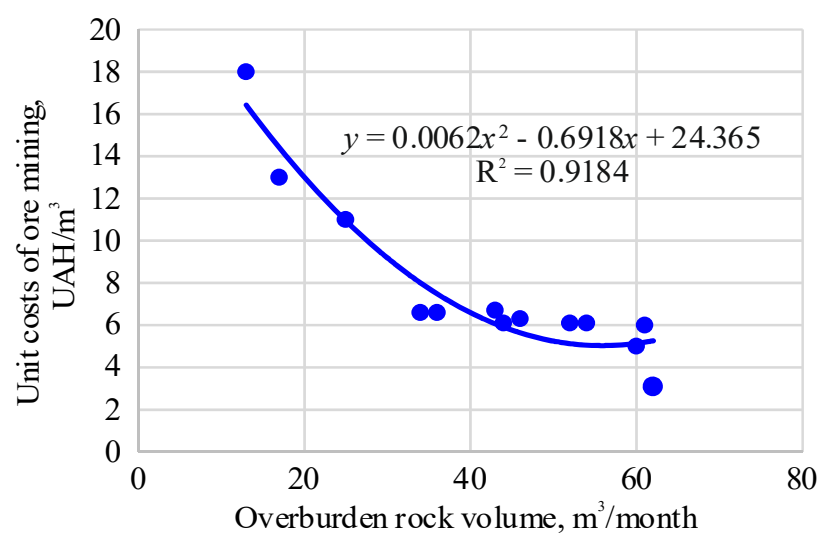

(b)

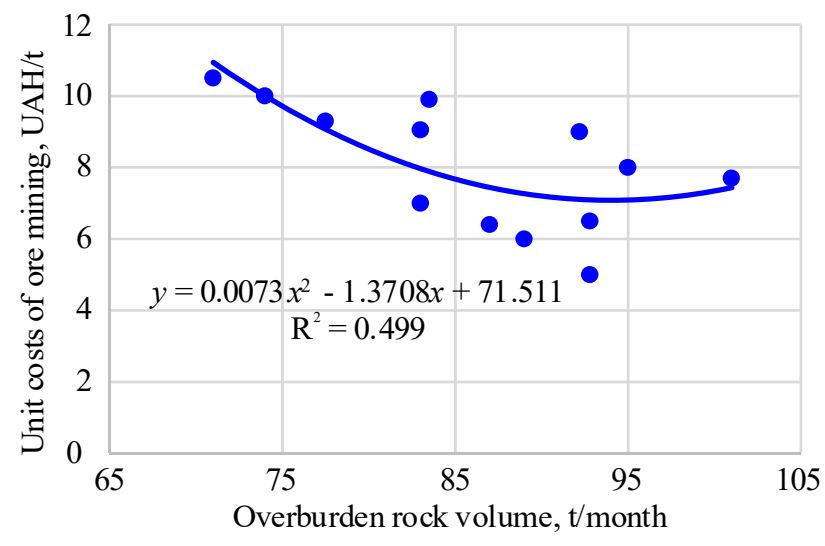

Figure 3. Graph of overburden unit costs dependence on the output in the context of Zaporizkyi open pit (a) and Pivnichnyi open pit (b)

It is expedient to use transport less system (i.e. above-ore bench) and transport-and-dumping system (i.e. heading bench and basic bench) for the open pit. Figure 4 demonstrates cross-section of the rock mass, and the open pit equipment.

The operation scheme, being proposed, involves the use of a rotary system consisting of SRs-2400 excavator and A2RS-880 stocker to mine overburden rock mass (i.e. dumping wall) with $53 \mathrm{~m}$ thickness (Fig. 4). The rock mass includes subbench of $36 \mathrm{~m}$ height and heading bench of $17 \mathrm{~m}$ height which is dumped to a service platform of SRs-2400 excavator by means of ESh-15/90 dragline. Two ESh-15/90 draglines form extra capacity within the stock to arrange rocks from the stockpile. Entry way is $35 \mathrm{~m}$.

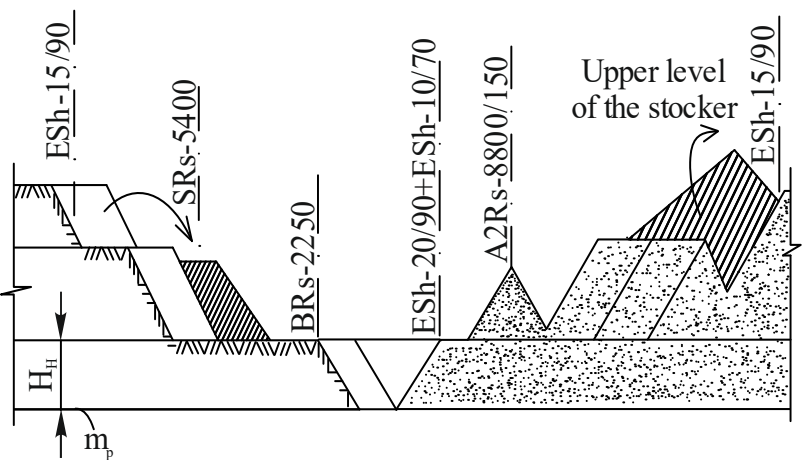

Figure 4. Scheme of ore seam extraction in the context of the decreased mining amount (cross-sections of a highwall and dumping wall)

Above-ore bench of $17 \mathrm{~m}$ height is mined with the help of ESh-20/90 dragline together with ESh-10/70 dragline. The ore is extracted by means of separated bench using either the excavator of a shovel type or a loader. The equipment required efficiency has been determined while comparing cross-sections of excavator entry way and rotary excavator SRS-2400. Overexavation coefficient is $0.92 \mathrm{~m}^{3} / \mathrm{m}^{3}$. Potential mining amount, being 682 thousand $\mathrm{t} / \mathrm{year}$ has been calculated on the formula:

$Q_{p}=\frac{Q_{c} m_{p} \gamma}{H_{n}}=\frac{2900 \cdot 2 \cdot 2}{17}=682$ thous. t,

where:

$H_{n}$ - a height of above-ore bench of overburden rocks, $\mathrm{m}$;

$Q_{c}$ - the amount of overburden operations within the above-ore bench, $\mathrm{m}^{3} \mathrm{p} / \mathrm{y}$ in the pillar;

$m_{p}$ - average thickness of the ore bed, $\mathrm{m}$;

$\gamma$ is crude ore density, $\mathrm{t} / \mathrm{m}^{3}$.

The proposed operation schedule provides overburden operations by means of the direct rock stockpiling to a stock excluding the use of conveyor facilities. Mining operations are performed by means of the separated bench with the help of loader and dumpers delivering the ore to the open pit wall.

Table 2 contains economic estimation of reconstruction efficiency of Pivnichnyi open pit according to the above schedule to compare with the actual schedule in the context of which overburden rock mass is mined by means of three benches.

Table 2. Expenditures connected with overburden operations in the context of bench mining

\begin{tabular}{|c|c|c|c|c|c|c|}
\hline \multirow[b]{2}{*}{$\begin{array}{c}\text { Location } \\
\text { of the equipment }\end{array}$} & \multicolumn{3}{|c|}{ Actual schedule } & \multicolumn{3}{|c|}{ Proposed schedule } \\
\hline & $\begin{array}{l}\text { Prime cost, } \\
\mathrm{UAH} / \mathrm{m}^{3}\end{array}$ & $\begin{array}{l}\text { The amount of } \\
\text { overburden } \\
\text { operations, } \\
\text { thous. } \mathrm{m}^{3} / \text { year }\end{array}$ & $\begin{array}{c}\text { Expenditures, } \\
\text { UAH } \\
\text { thous/year }\end{array}$ & $\begin{array}{l}\text { Prime cost, } \\
\mathrm{UAH} / \mathrm{m}^{3}\end{array}$ & $\begin{array}{l}\text { The amount of } \\
\text { overburden } \\
\text { operations, } \\
\text { thous. } \mathrm{m}^{3} / \text { year }\end{array}$ & $\begin{array}{c}\text { Expenditures, } \\
\text { UAH } \\
\text { thous/year }\end{array}$ \\
\hline Heading bench & 7.5 & 2900 & 21740 & 3.5 & 2900 & 10150 \\
\hline Basic bench & 6.4 & 6140 & 39296 & 5.4 & 9040 & 48816 \\
\hline Above-ore bench & 6.0 & 2900 & 17400 & 5.2 & 2900 & 15080 \\
\hline Total & - & 11940 & 78436 & - & 11940 & 74046 \\
\hline Per 1 ton of ore, UAH & - & - & 115.0 & - & - & 108.5 \\
\hline $\begin{array}{l}\text { Decrease in expenditures, } \\
\text { UAH thous./year }\end{array}$ & - & - & - & - & - & 4390 \\
\hline
\end{tabular}


The analysis of manufacturing expenses of Pivnichny open pit, connected with overburden operations in the context of the actual schedule and proposed one has shown that schedule two decreases overburden cost of a ton of ore by UAH 6.5 (i.e. 5.6\%). Owing to its implementation, the enterprise may save UAH $4.39 \mathrm{mln} /$ year. In this context, production capability of the open pit experiences almost double decrease (i.e. from 1375 down to 682 thous. $t /$ year); however, competitiveness of the integrated works product increases improving its market position as well its financial status.

\section{CONCLUSIONS}

Ukrainian mining and processing integrated works pay insufficient attention to equipment and technology reconstruction due to the decreased market demand for their product. The decreased demand resulted in the considerable increase of its prime cost and deterioration of the competitivity. Today, introduction of transportless delivery of overburden rocks to internal stockpile by means of draglines is efficient tendency to improve operation schedules of overburden operations in the context of manganese open pits since it provides the decrease in manufacturing expenditures in the context of the decreased demand for manganese ore.

Production function of Pivnichnyi open pit has been determined. According to the results of its analysis, the use of powerful overburden draglines makes it possible to cut work force while increasing manufacturing amount. To compare with open pits, operating on transport and dumping system, the open pit, using transportless system, gives quicker response to the increase in assets and personnel. For the obtained function, a sum of flexibility coefficients is $\alpha+\beta>1$ which means increasing productive capacity matching intensive economic growth.

Overburden operations are the basic component of production cost while crude ore extracting (i.e. $80-85 \%$ ); prime cost of the operations increases considerably if their volume drops due to significant increase in the specific semi-fixed costs since they are $60-70 \%$ of total overburden expenditures when ore mining is $33-38 \%$, and concentrate production is $46-50 \%$.

As for the statistic dependences of Pivnichnyi open pit and Zaporizkyi open pit, decreased amount of mining results in disproportionally low decrease of total production cost factoring into the accelerated appreciation of the extracted ore prime cost. The dependence may be avoided if powerful expensive equipment is replaced by cheaper and less productive facilities. The decreased production amount of mining enterprise (in accordance with market demand) stipulates smaller profit as against the previous acceptable profit of the mining and processing integrated works. According to the aspect, expediency of manufacturing activities by the integrated works should involve additional economic substantiation.

\section{ACKNOWLEDGMENTS}

The authors express gratitude to everyone who favoured (directly or indirectly) the origination of the methodological approach being essentially innovative technological model to support competitiveness of mining enter- prises. In particular, cooperation of the authors with the Department of Open-Pit Mining of the Dnipro University of Technology especially with Professor B.Yu. Sobko turned out to be determinative. The authors express kindly their thanks to Professor O.A. Temchenko from Kryvy Rih Economic Institute for his effective help rendered at the stage when scientific background of the general approach was being developed.

\section{REFERENCES}

Bilotserkivets, V.V., \& Zavhorodnia, O.O. (2017). Innovative challenges and post-crisis prospects of Ukrainian mining and metallurgical industry. Naukovyi Visnyk Natsionalnoho Hirnychoho Universytetu, (2), 149-156.

Dychkovskyi, R.O., Avdiushchenko, A.S., Falshtynskyi, V.S., \& Saik, P.B. (2013). On the issue of estimation of the coal mine extraction area economic efficiency. Naukovyi Visnyk Natsionalnoho Hirnychoho Universytetu, (4), 107-114.

Koltunovish, A. (2014). Ukraine is in drastic transformation into EU raw-material appendage. Ukrainian choice.

Kravchuk, I.L., \& Andreieva, L.I. (2012). Evaluating the potential of a mining enterprise and its use on the basis of improvement of the organization and management systems. Mining Informational and Analytical Bulletin, (11), 184-189.

Melnikov, A.M., Sobko, B.Yu., \& Pundiak, N.B. (2012). Analyzing the tendencies of changes in market environment and trends in the formation of mining enterprise development. Naukovyi Visnyk Natsionalnoho Hirnychoho Universytetu, (5), 121-126.

Mormul, T.M., \& Terekhov, Ye.V. (2017). Environmental and economic estimation of technological solutions in terms of land resource conservation in the process of open-cast mining. Naukovyi Visnyk Natsionalnoho Hirnychoho Universytetu, (3), 122-128.

National program for the development of raw-materials base of Ukraine up to the year of 2030. (2018). Official site of Verkhovna Rada of Ukraine [online]. Available at: http://zakon3.rada.gov.ua/laws/show/3268-17

Naumenko, O.V. (2013). Tendencies in the improvement of investment attractiveness of an enterprise with the purpose of its progress. Development Managements, (21), 21-23.

Opara, V., Buzina, I., \& Vynohradenko, S. (2017). Environmental-economic efficiency of land use improvement reasoning. Visnyk of V.N. Karazin Kharkiv National UniversitySeries Geology Geography Ecology, (46), 152-157. https://doi.org/10.26565/2410-7360-2017-46-21

Petlovanyi, M.V., Lozynskyi, V.H., Saik, P.B., \& Sai, K.S. (2018). Modern experience of low-coal seams underground mining in Ukraine. Article in press. International Journal of Mining Science and Technology, 28(6), 917-923. https://doi.org/10.1016/j.ijmst.2018.05.014

Pivnyak, G.G., Pilov, P.I., Bondarenko, V.I., Salli, V.I., \& Yashchenko, Yu.P. (2005). Internal reserves of efficiency rise in the coal industry in the conditions of market transformation of the Ukrainian economics. Gornyi Zhurnal, (5), 61-63.

Piwniak, G.G., Bondarenko, V.I., Salli, V., Pavlenko, I.I., \& Dychkovskiy, R.O. (2007). Limits to economic viability of extraction of thin coal seams in Ukraine. Technical, Technological and Economical Aspects of Thin-Seams Coal Mining, 129-132. https://doi.org/10.1201/noe0415436700.ch16

Ponomarenko, T.V., \& Sultani, A.N. (2009). Models to evaluate the potential of competitiveness of a mining enterprise. The Mining Institute Notes, (184), 70-75.

Ranängen, H., \& Lindman, Å. (2017). A path towards sustainability for the Nordic mining industry. Journal of Cleaner Production, (151), 43-52. https://doi.org/10.1016/j.jclepro.2017.03.047 
Rudko, G., Kurylo, M., \& Bala, V. (2016). Geological and economic assessment of coal deposits: contrasting national and international taxonomies in estimating reserves and resources. Visnyk of Taras Shevchenko National University of Kyiv. Geology, (72), 76-80. https://doi.org/10.17721/1728-2713.72.11

Savchenko, T.V. (2015). Effect of environmental factors upon the system of enterprise competitiveness management. Naukovyi Visnyk Natsionalnoho Hirnychoho Universytetu, (5), 142-148.

Shutov, N. (2012). The things we import and export. Ports of Ukraine.

Smol, M., Kulczycka, J., \& Avdiushchenko, A. (2017). Circular economy indicators in relation to eco-innovation in European regions. Clean Technologies and Environmental Policy, 19(3), 669-678.

https://doi.org/10.1007/s10098-016-1323-8

Strpić, K., Miličević, M., \& Kurevija, T. (2017). Development of tight oil resources in the USA: Exploitation costs and effect of macroeconomic indicators in a volatile oil price environment. Rudarsko Geolosko Naftni Zbornik, 32(3), 23-33. https://doi.org/10.17794/rgn.2017.3.3

Tatarkin, A.I., Kornolkov, S.V., Yakovlev, V.L., \& Orlova, Ye.A. (2012). Prognosis of technological development in mining industries on the basis of modernization of mining equipment and techniques. Regional Economy, 4(32), 80-92.
Temchenko, O.A. (2014). Studying the effect of the parameters of open-pit mining technology upon the efficiency of ironore deposits development. Naukovyi Visnyk Natsionalnoho Hirnychoho Universytetu, (1), 16-21.

Ursul, A., \& Ursul, T. (2015). Towards a global sustainable future. Philosophy and Cosmology, (15), 110-160.

Ursul, A., Ursul, T., \& Dugarova, M. (2017). Towards a global sustainable future. Philosophy and Cosmology, (15), 37-50.

Vahonova, O.H., \& Romaniuk, N.M. (2014). Economic justification of stages of the investment project of a mining and processing enterprise. Naukovyi Visnyk Natsionalnoho Hirnychoho Universytetu, (3), 159-164.

Vagonova, O., Prokopenko, V., \& Kyrychenko, A. (2014). Attractive technological and economic aspects of Ukrainian coal production development. Progressive Technologies of Coal, Coalbed Methane, and Ores Mining, 491-497. https://doi.org/10.1201/b17547-83

Voloshyna, S.V., \& Kostakova, L.D. (2017). Simulation analysis of relationship between production cost and natural environment of iron ore extraction and processing. Naukovyi Visnyk Natsionalnoho Hirnychoho Universytetu, (4), 112-121.

Vagonova, O.G., \& Volosheniuk, V.V. (2012). Mining enterprises' economic strategies as derivatives of nature management in the system of social relations. Naukovyi Visnyk Natsionalnoho Hirnychoho Universytetu, (2), 127-134.

Vagonova, O.G., \& Prokopenko, V.I. (2017). Competitiveness of national open-pit dumpers. Dnipro:NMU.

\section{АКТУАЛЬНІ ПИТАННЯ РОЗВИТКУ ТЕХНОЛОГІЇ ТА ЕКОНОМІКИ ЕКСПЛУАТАЦІЇ РОДОВИЩ КОРИСНИХ КОПАЛИН}

\section{О. Вагонова, Т. Мормуль, Ю. Захарченко, Н. Романюк, Л. Касьяненко}

Мета. Розробка адаптації гірничих підприємств до зміни кон'юнктури ринку їхньої продукції на основі забезпечення іiі конкурентоспроможності шляхом зниження витрат на видобування мінеральної сировини за рахунок реконструкції технологічної схеми гірничих робіт згідно з ринковим попитом на продукцію.

Методика. 3 використанням методу кореляційного аналізу, враховуючи мінливість та невизначеність вихідних даних, обгрунтовано методичний підхід до забезпечення конкурентоспроможності виробленої продукції в аспекті іiі адаптації до ринкового попиту. Спосіб підтримки конкурентних переваг продукції визначений на підставі виробничої функції гірничодобувного комплексу, оскільки ці переваги значною мірою обумовлені витратами на рудну сировину. Зміна витрат під впливом ринкового попиту оцінена на основі технікоекономічного аналізу досвіду роботи обраних до розгляду кар'єрів.

Результати. Встановлений взаємозв'язок між технологією видобування рудної сировини, собівартістю продукції гірничо-збагачувальних комбінатів України та ринковим попитом на їхню продукцію. Для підвищення іï конкурентоспроможності визначено теперішні витрати кар'єру на розробку рудного пласта та обгрунтовано на їх підставі технологічні рішення щодо реконструкції діючого гірничодобувного комплексу. Наведений вплив системи розробки на технологічну адаптацію комплексу гірничих робіт до зниженого попиту на марганцеву руду.

Наукова новизна. Розроблено науково-прикладні засади підтримання конкурентних переваг продукції гірничо-збагачувальних комбінатів шляхом технологічної адаптації гірничодобувних комплексів до ринкового попиту. Важелі адаптації комплексів оцінені за допомогою виробничої функції. Вдосконалено методичний підхід до планування собівартості рудної сировини, що грунтується на структурі витрат на розкривні роботи.

Практична значимість. Стосовно Північного й Запорізького кар'єрів визначений вплив обсягу гірничих робіт на собівартість видобутої руди, з урахуванням цього впливу економічно обгрунтована доцільна система розробки рудного уступу. Встановлена виробнича функція Північного кар'єру. За результатами ії аналізу сформульовані рекомендації щодо скорочення робочої сили й підвищення обсягу виробництва.

Ключові слова: гірничо-збагачувальне підприємство, марганцеві кар'єри, виробнича функиія, конкурентоспроможність, продукція

\section{АКТУАЛЬНЫЕ ВОПРОСЫ РАЗВИТИЯ ТЕХНОЛОГИИ И ЭКОНОМИКИ ЭКСПЛУАТАЦИИ МЕСТОРОЖДЕНИЙ ПОЛЕЗНЫХ ИСКОПАЕМЫХ}

\section{А. Вагонова, Т. Мормуль, Ю. Захарченко, Н. Романюк, Л. Касьяненко}

Цель. Разработка адаптации горных предприятий к изменению конъюнктуры рынка их продукции на основе обеспечения ее конкурентоспособности путем снижения затрат на добычу минерального сырья за счет реконструкции технологической схемы горных работ в соответствии с рыночным спросом на продукцию. 
Методика. С использованием метода корреляционного анализа, учитывая изменчивость и неопределенность исходных данных, обоснован методический подход к обеспечению конкурентоспособности произведенной продукции в аспекте ее адаптации к рыночному спросу. Способ поддержания конкурентных преимуществ продукции определен на основании производственной функции горнодобывающего комплекса, поскольку эти преимущества в значительной степени обусловлены затратами на рудное сырье. Изменение затрат под влиянием рыночного спроса оценена на основе технико-экономического анализа опыта работы избранных к рассмотрению карьеров.

Результаты. Установлена взаимосвязь между технологией добычи рудного сырья, себестоимостью продукции горно-обогатительных комбинатов Украины и рыночным спросом на их продукцию. Для повышения ее конкурентоспособности определены нынешние затраты карьера на разработку рудного пласта и обоснованы на их основании технологические решения по реконструкции действующего горнодобывающего комплекса. Приведено влияние системы разработки на технологическую адаптацию комплекса горных работ к пониженному спросу на марганцевую руду.

Научная новизна. Разработаны научно-прикладные основы поддержания конкурентных преимуществ продукции горно-обогатительных комбинатов путем технологической адаптации горнодобывающих комплексов с рыночным спросом. Рычаги адаптации комплексов оценены с помощью производственной функции. Усовершенствован методический подход к планированию себестоимости рудного сырья, базирующийся на структуре затрат на вскрышные работы.

Практическая значимость. Относительно Северного и Запорожского карьеров определено влияние объема горных работ на себестоимость добытой руды, с учетом этого влияния экономически обоснована целесообразная система разработки рудного уступа. Установлена производственная функция Северного карьера. По результатам ее анализа сформулированы рекомендации по сокращению рабочей силы и повышению объема производства.

Ключевые слова: горно-обогатительное предприятие, марганцевые карьеры, производственная функция, конкурентоспособность, продукция

\section{ARTICLE INFO}

Received: 22 April 2018

Accepted: 21 November 2018

Available online: 10 December 2018

\section{ABOUT AUTHORS}

Oleksandra Vagonova, Doctor of Economic Sciences, Head of the Applied Economics and Entrepreneurship Department, Dnipro University of Technology, 19 Yavornytskoho Ave., 49005, Dnipro, Ukraine. E-mail: vagonovaag@gmail.com

Taras Mormul, Candidate of Technical Sciences, Associate Professor of the Economics and Entrepreneurship Department, Dnipro University of Technology, 19 Yavornytskoho Ave., 49005, Dnipro, Ukraine. E-mail: mormult33@gmail.com

Yuliia Zakharchenko, Senior Lecturer of the Marketing Department, State Agrarian and Economic University, 25 Yefremova St, 49027, Dnipro, Ukraine. E-mail: zacharchenko@list.ru

Nataliia Romaniuk, Candidate of Economic Sciences, Associate Professor of the Economics and Entrepreneurship Department, Dnipro University of Technology, 19 Yavornytskoho Ave., 49005, Dnipro, Ukraine. E-mail: romnat07@rambler.ru

Liliia Kasianenko, Candidate of Economic Sciences, Associate Professor of the Economics and Entrepreneurship Department, Dnipro University of Technology, 19 Yavornytskoho Ave., 49005, Dnipro, Ukraine. E-mail: tommy_girl@ua.fm 